Patrícia Póvoa Mattos', Evaldo Muñoz Braz', Vitor Dressano Domene², Everardo Valadares de Sá Barretto Sampaio ${ }^{3}$, Peter Gasson ${ }^{4}$, Frans Germain Corneel Pareyn ${ }^{5}$, Ivan Andre Alvarez ${ }^{6}$, Amélia Baracat ${ }^{4}$, Elcida de Lima Araújo ${ }^{7}$

\title{
CLIMATE-TREE GROWTH RELATIONSHIPS OF Mimosa tenuiflora IN SEASONALLY DRY TROPICAL FOREST, BRAZIL
}

Keywords:

Dendrochronology

Caatinga

Forest management

Historic:

Recebido 07/02/2012

Aceito $31 / 08 / 2014$

Palavras chave:

Dendrocronologia

Caatinga

Manejo florestal

Correspondence: patricia.mattos@embrapa.br

DOI:
ABSTRACT: Mimosa tenuiflora is a native pioneer tree from the Caatinga used commercially as firewood due to its high calorific value. It is deciduous, its trunk does not reach large diameters and it has good regrowth capacity. This study intended to determine the annual increment in diameter of $M$. tenuiflora and its correlation with rainfall, as basis for fuel wood management. Disks from the stem base of $M$. tenuiflora trees were collected in 2008 in Sertânia and Serra Talhada, Pernambuco State, from regrowth of trees coppiced in 2003 and in Limoeiro do Norte, Ceará State, from a plantation established in 2002. The trees have well-defined annual growth rings, highly correlated with annual precipitation and are well-suited for dendrochronological investigations. Forest managers must consider the influence of previous drier years in the wood production when predicting fuel wood harvesting. The high growth correlation with the previous year's rainfall in regions where the rains start after photoperiodic stimulation indicate the necessity of understanding the growth dynamics of the species under dry forest conditions through additional ecophysiology studies.

\section{RELAÇÃO CLIMA-CRESCIMENTO DE ÁRVORES DE Mimosa tenuiflora EM FLORESTA TROPICAL SECA SAZONAL, BRAZIL}

RESUMO: Mimosa tenuiflora é uma árvore pioneira e nativa da Caatinga usada, comercialmente, para lenha, em razão do seu elevado poder calorífico. É decídua, com perda de folhas no final da estação chuvosa, seu tronco não atinge grandes diâmetros e tem boa capacidade de rebrota. Este estudo tem por objetivo determinar o incremento anual em diâmetro de $M$. tenuiflora e sua correlação com a precipitação, visando a subsidiar o manejo florestal de madeira para energia. Discos da base do tronco de árvores de $M$. tenuiflora foram coletados em 2008, em Sertânia e Serra Talhada, Pernambuco, a partir de rebrota de árvores manejadas com corte raso em 2003 e em Limoeiro do Norte, de um plantio estabelecido em 2002. Árvores de Mimosa tenuiflora da Caatinga apresentam anéis anuais de crescimento bem definidos altamente correlacionadas com a precipitação anual e adequados para estudos dendrocronológicos. Os administradores florestais devem considerar a influência de anos prévios mais secos na produção de madeira, a fim de prever seu ciclo de corte. A correlação de crescimento elevado com chuvas do ano anterior em regiões onde as chuvas iniciam após a estimulação fotoperiódica, indicam a necessidade de compreender a dinâmica de crescimento das espécies florestais em condições secas, por meio de estudos ecofisiológicos.

' Embrapa Florestas - Colombo, Paraná, Brazil

2 Universidade Federal do Paraná - Curitiba, Paraná, Brazil

${ }^{3}$ Universidade Federal de Pernambuco - Recife, Pernambuco, Brazil

${ }^{4}$ Royal Botanic Gardens - Richmond, Surrey, United Kingdom

${ }^{5}$ Associação Plantas do Nordeste - Recife, Pernambuco, Brazil

${ }^{6}$ Embrapa Monitoramento por Satélite - Campinas, São Paulo, Brazil

${ }^{7}$ Universidade Federal Rural de Pernambuco - Recife, Pernambuco, Brazil 


\section{INTRODUCTION}

Many areas of degraded tropical forests are inhabited by poor communities, strongly dependent on forest resources for their livelihood (ALVAREZ et al., 20 I I; CUVILAS et al., 20I0; MIAH et al., 2009). Most of these communities have no access to protocols to use forest resources without degrading the forest, and that is even more drastic when considering site-specific characteristics. This is the reality in the semi-arid caatinga of northeast Brazil. This seasonally dry forest has a high diversity of species, many of which are endemic (GIULIETTI et al., 2002). Despite the caatinga's botanical richness, the high demand for fuel wood or charcoal by local industry and for domestic use means that there is unsustainable legal and illegal overexploitation of the vegetation (RIEGELHAUPT; PAREYN, 2010). This is amplified by agricultural pressure and has resulted in the vegetation modification of $70 \%$ of the original forest cover (ALVES et al., 2009). Local users acknowledge that the stock of wood and charcoal in the Caatinga is in decline. Moreover, the devastation that is occurring to fulfill economic activities, associated with the fragility of the ecosystem, causes a reduction in biological diversity, compromising water resources, increasing soil erosion, soil compaction and salinization, and reducing primary production (ALVES, 2007).

Some authors consider that the implementation of sustainable management techniques in tropical dry forests could provide an economic return without damaging these areas (FIGUEIROA et al., 2006; MOSTACEDO et al., 2009; VILLEGAS et al., 2009). One of the limitations in implementing management plans is the lack of reliable data about mean annual increments (MAl) of woody species in natural and managed conditions (PRIOR et al., 2006).

One rapid and efficient way of quantifying $\mathrm{MAl}$ is by measuring growth rings. Annual rings allow recovery of information on growth with precision and help to understand the dynamics of growth in relation to seasonality. In dry tropical regions several studies show a positive correlation between growth and precipitation (BRIENEN et al., 20I I; ENQUIST; LEFFLER, 200 I; FICHTLER et al., 2004; MATTOS; SEITZ, 2008; SCHONGART et al., 2006; VOLLAND-VOIGT et al., 20II; WILS et al., 201 I; WORBES et al., 2003). Many researchers also apply the ring-width data to calculate the intervals of cutting cycles of natural forest in the tropics (BRIENEN; ZUIDEMA, 2006; COURALET et al., 2005; MATTOS et al., 2010; SCHONGART, 2008).

Several species are used for domestic wood and charcoal in the Caatinga, including Mimosa tenuiflora, which has proven value in forest management and energy supply. Its wood is dense and the tree regenerates rapidly after cutting or fire (BAKKE et al., 2007; FIGUEIROA et al., 2006; SILVA et al., 2009), and the species frequently appears in phytosociological surveys of semi-arid regions in Brazil (FREITAS et al., 2007; LACERDA et al., 2005). The objective of this work is to contribute to the understanding of growth dynamics and the influence of rainfall on annual radial growth in stems of Mimosa tenuiflora in different areas and under different management systems, to subsidize the sustainable use of this forest resource.

\section{MATERIAL AND METHODS}

The geoecology domain of caatinga extends for about $900.000 \mathrm{~km}^{2}$, in the semi-arid region of Northeast Brazil, from $2^{\circ} 45^{\prime} S$ to $17^{\circ} 21$ 's (ALVES, 2007). This region is characterized by low annual rainfall and high evapotranspiration rates. Periodically, it experiences intense drought (SILVA, 2004).

Disk samples from the stem base of Mimosa tenuiflora trees were obtained, in the end of 2008, from management experiments in three municipalities in the semiarid region: Sertânia (0804'02,7'S 37I2'33, I'W) and Serra Talhada (07055'46,4'S 38'I7'20,0'W), in Pernambuco State, and Limoeiro do Norte $\left(05^{\circ} 08^{\prime} 44^{\prime \prime S}\right.$ $\left.38^{\circ} 05^{\prime} 53^{\prime \prime} \mathrm{W}\right)$ in Ceará State. The rainy season occurs from January to May in all three areas, with large variation in rainfall distribution among these months and from one year to another. The long term average rainfall in Sertânia is $554 \mathrm{~mm}$, in Serra Talhada is $618 \mathrm{~mm}$ and in Limoeiro do Norte is $724 \mathrm{~mm}$ (data provided by LAMEPE/ITEP for Pernambuco and FUNCEME for Ceará). Rainfall from 2001 to 2008 is presented in Figure 1. Soils in Sertânia and Serra Talhada have a coarse sandy texture, with median fertility, and those in Limoeiro do Norte are Cambisols, with median to high fertility (FIGUEIROA et al., 2006).

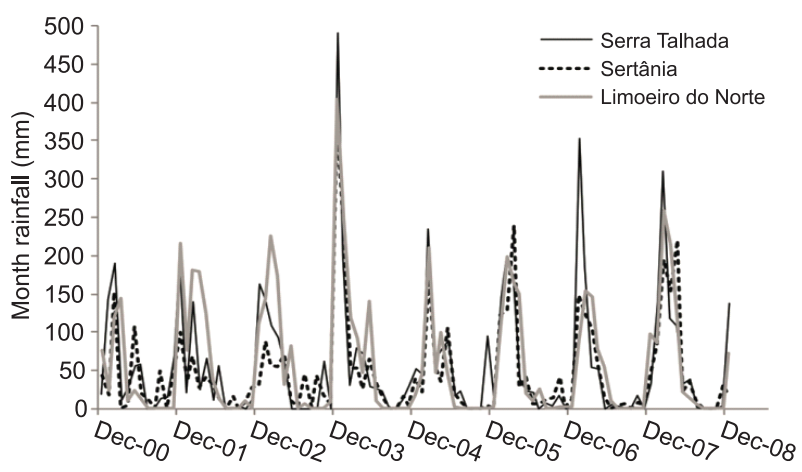

FIGURE 1 Monthly rainfall at Sertânia and Serra Talhada (PE) and at Limoeiro do Norte (CE), between 2001 and 2008.

FIGURA 1 Precipitação mensal em Sertânia e Serra Talhada (PE) e em Limoneiro do Norte (CE), entre 2001 e 2008. 
The trees in Sertânia and Serra Talhada were chosen from caatinga stands that were clear cut in 2002. Therefore, they were 6-year-old regrowth plants and were mingled with trees belonging to other species. The trees in Limoeiro do Norte were transplanted to the field in 2003 from seedlings prepared in the previous year. The field had been cleared of vegetation and disked before the planting holes were opened. The holes were opened each $1.5 \mathrm{~m}$ along rows $3 \mathrm{~m}$ apart, forming pure stands of $M$. tenuiflora.

The stem cross-sections were cut about 10 $\mathrm{cm}$ above the soil. A cross-section was obtained from each one of the six trees cut at Sertânia, nine trees at Serra Talhada and ten trees at Limoeiro do Norte. Samples were air dried and had their surface sanded and polished for better observation of the growth rings. The rings from each disc were marked, counted and measured in four rays, using a stereoscopic microscope and table for measuring rings, with $0.01 \mathrm{~mm}$ precision. Since the growth ring series are short, the measured increments were considered, without transforming to unbiased ring indices.

The growth ring series were dated visually by a graphic analysis in a spreadsheet. A master series was generated for each site. The correlation of each tree with the master series was calculated and the average correlation determined for each site.

The values of the ring widths were compared by Pearson correlation with the rainfall values of the years prior to their formation, considering each year as beginning in August of previous year and finishing in July of current year, in order to include the rainy period (when most of the plant growth occurs) in one year. Thus, for example, the year designated as 2003 corresponds to the rainfall between August 2002 and July 2003.

To verify if there were growth differences in and among sites, the ring widths of the three sites were submitted to variance analysis, considering a complete randomized design with different replications, represented by the number of trees in each site. The annual rainfall along the six year period of the study in the three areas were also submitted to analysis of variance considering the sites as replications for the comparison of years and considering the years as replications for the comparison of sites. The averages were compared using the Tukey test at $5 \%$ probability level. Considering the low number of cases, they were amplified by simulations following a bootstrap procedure (DAVISON; HINKLEY, 1997), as was done by Brienen (2005). The bootstrap simulations generated growth rings for 1,000 trees for each studied site, for 6 years. Individual trees growth models were fitted to each site, considering the models: Bertalanfy, Gama, Gompertz, Logistic, Mitcherlich, Schumacher and Weibull. The selection of the best growth model was based on $\mathrm{R}^{2}, \mathrm{Syx} \%, \mathrm{~F}$ value and residues analysis.

\section{RESULTS}

\section{Formation of annual growth rings}

Most of the trees (88\%) had cross-sections with six growth rings, corresponding to their age of six years, known from their planting or sprouting date. Three individuals from Serra Talhada had only five growth rings, which were cross-dated with a series of annual increments from other trees. The average correlation between the growth ring series and the master series of each study site were 0.70 for Sertânia, 0.4 I for Serra Talhada and 0.60 for Limoeiro do Norte.

The mean annual increment (MAI) in Limoeiro do Norte $\left(1.02 \mathrm{~cm} \cdot y^{2} \mathrm{r}^{-1}\right)$ was higher and significantly different by the Tukey test at $5 \%$ probability level than those of the other two locations, which did not significantly differ $\left(0.54 \mathrm{~cm} \cdot\right.$ year $^{-1}$ for Sertânia and 0.60 $\mathrm{cm} \cdot$ year' ${ }^{-1}$ for Serra Talhada).

The Gama equation was the growth model with the best fit for Serra Talhada and Sertânia data and the Schumacher equation the best fit for Limoeiro do Norte data, considering coefficients of determination $\left(R_{\text {adjust }}^{2}\right)$, standard errors of the estimate, $F$ values (Table 1 ) and residues distribution.

TABLE 1 Parameters of growth models of Mimosa tenuiflora from Sertânia, Serra Talhada and Limoeiro do Norte. Gamma model: $\mathrm{DSH}=\mathrm{B}_{0}{ }^{*}\left(\text { year } / \mathrm{B}_{1}\right)^{\wedge}\left(\mathrm{B}_{2}{ }^{*} \exp \left(\mathrm{B}_{0} / \mathrm{B}_{1}\right)\right)$; Schumacher model: $\mathrm{DSH}=\mathrm{B}_{0}{ }^{*} \exp \left(-\mathrm{B}_{1}{ }^{*}(1 /\right.$ year $\left.)\right)$.

TABELA 1 Parâmetros de modelos de crescimento de Mimosa tenuiflora, de Sertânia, Serra Talhada e Limoeiro do Norte.

\begin{tabular}{llcccccc}
\hline Site & Growth model & $\beta_{0}$ & $\beta_{1}$ & $\beta_{2}$ & $R^{2}$ adj & Syx\% & Fcal \\
\hline Sertania & Gama & 0.7443 & 0.95 & 0.3643 & 0.96 & 30.70 & 225,279 \\
Serra Talhada & Gama & 0.5072 & 0.95 & 0.6259 & 0.96 & 31.90 & 303,609 \\
Limoeiro do Norte & Schumacher & 10.5087 & 3.2586 & - & 0.98 & 23.42 & 693,651 \\
\hline
\end{tabular}

DSH - Diameter at soil height, $\mathrm{R}_{\text {adj }}^{2}$ - coefficient of determination; Syx \% - standard error of the estimate; Fcal - $F$ value.

$D A B$ - Diâmetro ao nível do solo, $R_{\text {adj }}^{2}$ - coeficiente de determinação; Syx\% - erro padrão da estimativa; Fcal - valor de $F$. 
From the growth models presented in Figure 2, it is possible to observe that the trees from Limoeiro do Norte had a faster initial growth than the trees form the other sites and that their growth curve tended to stabilize before those of the other sites.

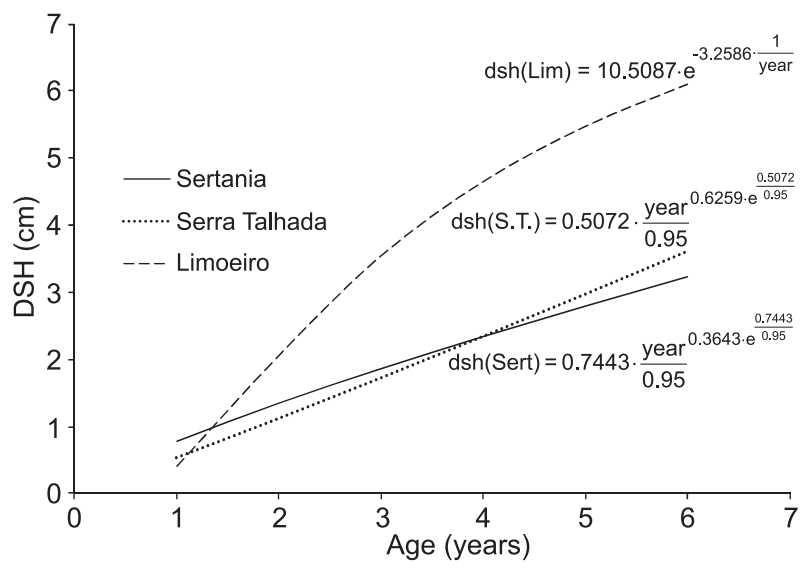

FIGURE 2 Growth models in base diameter of trees of Mimosa tenuiflora from Sertânia, Serra Talhada and Limoeiro do Norte. Dsh - diameter at soil height; S.T. - Serra Talhada; Sert - Sertânia; Lim - Limoeiro.

FIGURA 2 Equação de crescimento em diâmetro na base de árvores de Mimosa tenuiflora, de Sertânia, Serra Talhada e Limoeiro do Norte.

\section{Correlation with rainfall}

The average annual rainfall of the three municipalities over the six years were not significantly different, in spite of the slightly lower value in Serra Talhada: $615 \mathrm{~mm}$ versus $737 \mathrm{~mm}$ in Sertânia and 724 $\mathrm{mm}$ in Limoeiro do Norte. The average rainfall of the three municipalities (Table 2) in 2004 (974 mm) was higher than in other years (542 to $656 \mathrm{~mm}$ ) except 2008 $(801 \mathrm{~mm})$. However, the rainfall distribution along the year was different among the municipalities, mainly in the period from October to December that precedes the months of most concentrated rainfall and most plant growth. In this period, rainfall in Limoeiro do Norte was lower than in the other areas (Figure 3).

The correlation between the current annual rainfall and mean annual ring increment for each site was positive (Table 2). However, the correlation between rainfall in the previous year and the growth increment was positive only for the trees in Limoeiro do Norte and the correlation between the sum of the previous year's annual rainfall and that of the current year was positive for trees from Sertânia and Limoeiro do Norte (Table 3).
TABLE 2 Annual rainfall in $\mathrm{mm}$, covering the period from August to July of the following year, for Sertânia, Serra Talhada and Limoeiro do Norte.

TABELA 2 Precipitação anual em $\mathrm{mm}$, cobrindo o período de agosto a julho do ano seguinte, para Sertânia, Serra Talhada e Limoeiro do Norte.

\begin{tabular}{lcccc}
\hline & Sertânia & $\begin{array}{c}\text { Serra } \\
\text { Talhada }\end{array}$ & $\begin{array}{c}\text { Limoeiro do } \\
\text { Norte }\end{array}$ & Average \\
\hline 2003 & 629 & 426 & 784 & $613 \mathrm{~b}$ \\
2004 & 993 & 871 & 1059 & $974 \mathrm{a}$ \\
2005 & 695 & 461 & 469 & $542 \mathrm{~b}$ \\
2006 & 638 & 645 & 684 & $656 \mathrm{~b}$ \\
2007 & 678 & 488 & 533 & $566 \mathrm{~b}$ \\
2008 & 789 & 797 & 817 & $801 \mathrm{ab}$ \\
Average & $737 \mathrm{~A}$ & $615 \mathrm{~A}$ & $724 \mathrm{~A}$ & - \\
\hline
\end{tabular}

Results followed by the same letter are not significantly different by the Tukey test at $5 \%$ probability level.

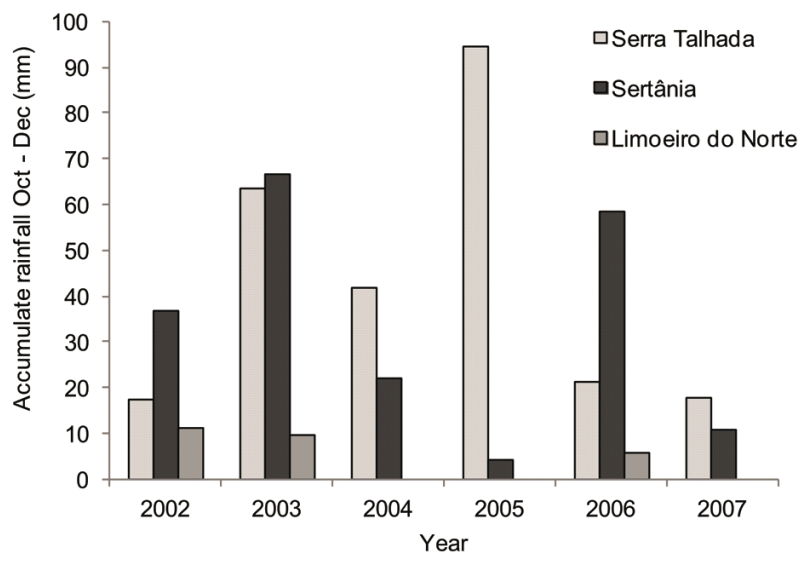

FIGURE 3 Rainfall between October and December, the period that precedes the growth seasons, for Sertânia, Serra Talhada and Limoeiro do Norte.

FIGURA 3 Precipitação pluviométrica entre outubro e dezembro, período que antecede a estação de crescimento, para Sertânia e Serra Talhada (PE) e Limoeiro do Norte (CE).

TABLE 3 Pearson correlation coefficients ( $r$ ) and its probability level ( $p$ ) between mean annual increment and annual rainfall for Sertânia, Serra Talhada and Limoeiro do Norte.

TABELA 3 Coeficiente de correlação de Person ( $r$ e o o nível de probabilidade $(p)$ entre o incremento médio anual e a precipitação para Sertânia, Serra Talhada e Limoeiro do Norte.

\begin{tabular}{lccccccc}
\hline \multirow{2}{*}{ Rainfall } & \multicolumn{2}{c}{ Sertânia } & \multicolumn{2}{c}{$\begin{array}{c}\text { Serra } \\
\text { Talhada }\end{array}$} & \multicolumn{2}{c}{$\begin{array}{c}\text { Limoeiro do } \\
\text { Norte }\end{array}$} \\
\cline { 2 - 8 } & $\mathrm{r}$ & $\mathrm{p}$ & $\mathrm{r}$ & $\mathrm{p}$ & $\mathrm{r}$ & $\mathrm{p}$ \\
\hline Current year & 37 & 0.05 & 53 & 0.05 & 29 & \\
Previous year & - & & - & & 78 & 0.01 \\
Current + previous & 55 & 0.01 & - & & 91 & 0.01 \\
\hline
\end{tabular}




\section{DISCUSSION}

The growth rings were distinct and delimited by axial parenchyma, as described previously by Silva et al. (20I I) for Mimosa tenuiflora trees. The rings reflect the well-defined annual period of growth characteristic of the seasonal climate in semi-arid regions. The rings were confirmed in trees of all three localities and their number matched the number of years of growth after planting or sprouting. Similar matching has been described for other tropical species of known age (CHOWDHURY et al., 2008; NICOLINI et al., 20I0).

The trees grew over years with variable climatic data, some with much lower annual rainfall than the historic means of the areas, as frequently occurs in the caatinga (VELLOSO et al., 2002). This frequently results in absence of a growth ring in the year, as described for seasonally dry forests in Ethiopia, but this this was not observed in the samples of this study. Even for the year 2005 with the lowest rainfall, distinct growth rings were formed, although with the lowest radial growth. Rainfall correlated positively with growth of $M$. tenuiflora, a similar result obtained in other tropical forest regions (WILS et al., 20I I). However, in Limoeiro do Norte, this correlation was low.

Differences in site characteristics, tree management, genetic variation and perhaps other factors, were sources of variation in growth among individuals. The trees sampled in Sertânia and Serra Talhada were at low density in unplanted natural forest while the trees at the experimental site of Limoeiro do Norte were grown in a monoculture plantation. These differences in site and management were probably the greatest cause for the higher mean annual increment in Limoeiro do Norte (Figure 2). Wood harvesting in a seven years plantation in Limoeiro do Norte would result in stems with a diameter of six or seven $\mathrm{cm}$ at the base. The selectively coppiced trees in Sertania and Serra Talhada (FIGUEIROA et al., 2006), based on MAI values of each site, would take around twelve to thirteen years to achieve the same diameter.

Several authors consider fuel wood stem and branch segments that present equal or above $4 \mathrm{~cm}$ in diameter (CAMPOS et al., 1986; MACHADO et al., 2008; STURION et al., 1988; STURION; TOMASELLI, 1990). Moreover, the average diameters at soil level of native plants of $M$. tenuiflora are frequently below 10 $12 \mathrm{~cm}$ (CALIXTO JÚNIOR et al., 20I I). So, trees with diameters higher than $6 \mathrm{~cm}$ could be and are used as fuel wood.
M. tenuiflora grew at least $44 \%$ more in the open areas with little competition of Limoeiro do Norte than in the two other sites. Measurements for six years, after coppicing in Sertânia and Serra Talhada, have already revealed low growth rates (FIGUEIROA et al., 2006). The selection of the management system should consider the performance of the species, but also the social organization and the financial availability to implement plantation instead of cropping management.

Considering that biomass estimations are usually based on equations considering diameter as independent variable (SAMPAIO et al., 20I0), and noting that in the dry season radial growth reduces or ceases, a historical climatic series needs to be considered to reduce the error in medium and long term projections of biomass production. On the other hand, the use of growth models generated by dendrochronological series that cover the evaluated growth period allow the inference monitoring of plant growth year by year and indirectly of biomass accumulation.

In phenological studies on caatinga species, Lima and Rodal (2010) found that, despite the strong influence of rainfall on leaf sprouting, many species, including Mimosa tenuiflora, sprout new leaves during the dry season. Borchert et al. (2002) also highlighted the influence of water stress and photoperiod on leaf fall, in dry tropical forest. Considering that the photoperiods are similar at the three sites and that only in Limoeiro do Norte very low rainfall occurs in the period that precedes the rainy season (January to April/May), the difference in correlation of annual increments and rainfall could be dependent on water reserves accumulated in the trees, in parenchyma cells for example. These reserves could contribute to the sprouting of new leaves and also to the formation of new cells in the cambium and ultimately the secondary xylem and phloem of the tree. Positive correlation with rainfall from the previous year occurred only in Limoeiro do Norte where the trees were planted without competition from other species. Another difference among the areas is the lower frequency of rain between October to December, preceding the rainy season, in Limoeiro do Norte. Therefore, there are two causes that could explain the different behavior in this area.

Lopez et al. (2006) studied the growth response to rainfall, temperature and El Niño (ENSO) in two naturally occurring species along the latitudinal gradient from Peru (Prosopis pallida) to central Chile (Prosopis chilensis). Despite the distance between the locations, the growth of the two species had similar positive correlations with rainfall. 
Fichtler et al. (2004) studied growth rings of Burkea africana and Pterocarpus angolensis in semi-arid forests of Namíbia. Burkea africana was more sensitive to variation in rainfall than $P$. angolensis in two locations. The growth response to rainfall was positive, but, there was a difference in timing of response between localities, corresponding to the beginning of the growing season, similar to our observations on Mimosa tenuiflora.

In Serra Talhada and Sertânia the plants behaved differently. In Serra Talhada photoperiod stimulated growth at the same time as rainfall which is more uniformly distributed, not correlating positively with rainfall from the previous year or with the sum of the previous and current year. It appears that the water provided by rainfall is sufficient for the plants not to rely on accumulated reserves at the beginning of the rainy season. In Sertânia, where rainfall immediately preceding the growing season is more irregular (in some years less than $10 \mathrm{~mm}$ in the three months from October to December, Table 3), there was a positive correlation in diameter growth with the sum of rainfall of the previous year with the current year.

Some deciduous plants from dry forest are tolerant to water stress and can replenish their water reserves even after less intense rainfall (BORCHERT et al., 2002). In Sertânia, we assume that the plants used their accumulated water reserves to satisfy the demand for growth stimulated by photoperiod. For many deciduous species growth is only initiated after the sprouting of new leaves, as shown for Celtis africana in Ethiopia (KREPKOWSKI et al., 20I I).

Markesteijn et al. (2010) also highlight the difference of tolerance and leaf phenology associated with soil water potential that suffers influence of temporal variation, mainly depending on the annual rainfall cycle and spatial variation that results from topography and vertical distribution of water in soil layers.

When the rainy season in Sertânia and Serra Talhada begins late, the trees could be stimulated by photoperiod to begin growth and use their accumulated reserves of water (from previous years) as they do in Limoeiro do Norte. There are strong indications that the differences in the beginning of the rainy season and the total rainfall of each year determine ring widths in Mimosa tenuiflora, and that the trees can be dependent on the plant water reserves from the previous year.

Toledo et al. (20II) observed, in a study in Bolivia, that the climate had a stronger influence than the soil on tree growth. Growth responses in the caatinga of valuable trees such as Mimosa tenuiflora are complex and need to be better understood because temperatures are increasing and relative humidity and rainfall are showing a decreasing trend in northeast Brazil (SILVA, 2004). Similar situations are occurring in different regions of tropical forest (LOPEZ; VILLALBA, 20II). The effects of rainfall variation in semi-arid Brazil, taking into account population growth and demands for land use have been modeled by Barbieri et al. (2010) and Krol and Bronstert (2007). Intense dry events have been attributed to "El Niño" (SILVA, 2004), and can be recognized by examination of growth ring patterns in dry forest species (BRIENEN et al., 20I0; FICHTLER et al., 2004; GEBREKIRSTOS et al., 2008; LOPEZ et al., 2006; RODRIGUEZ et al., 2005).

\section{CONCLUSIONS}

Mimosa tenuiflora from the caatinga has welldefined growth rings highly correlated with annual rainfall, and is well suited to dendrochronological studies.

Forest managers must consider the influence of previous drier years in the wood production and the management system when predicting fuel wood harvesting.

The high correlation with rainfall from the previous year where rain starts after stimulation by photoperiod indicates the need for better understanding of the growth dynamics of this species under semi-arid conditions through additional ecophysiological studies.

\section{REFERENCES}

ALVAREZ, J. A.; VILLAGRA, P. E.; VILLALBA, R.; CONY, M. A.; ALBERTO, M. Wood productivity of Prosopis flexuosa D.C. woodlands in the central Monte: influence of population structure and tree-growth habit. Journal of Arid Environment, London, v. 75, p. 7-I3, 201 I.

ALVES, J. J. A. Geoecologia da caatinga no semi-árido do nordeste brasileiro. Climatologia e Estudo da Paisagem, Rio Claro, v. 2, p. 58-7I, 2007.

AlVES, J. J. A.; ARAUjO, M. A.; NASCIMENTO, S. S. Degradação da caatinga: uma investigação ecogeográfica. Caatinga, Mossoró, v. 22, n. 3, p. I26-135, jul./set. 2009.

BAKKE, I. A.; BAKKE, O. A.; ANDRADE, A. P.; SALCEDO, I. $\mathrm{H}$. Forage yield and quality of a dense thorny and thornless "jurema preta" stand. Pesquisa Agropecuária Brasileira, Brasília, v. 42, p. 34I-347, 2007.

BARBIERI, A. F.; DOMINGUES, E.; QUEIROZ, B. L.; RUIZ, R. M.; RIGOTTI, J. I.; CARVALHO, J. A. M.; RESENDE, M. F. Climate change and population migration in Brazil's Northeast: scenarios for 2025-2050. Population and Environment, New York, v. 31, p. 344-370, 2010. 
BORCHERT, R.; RIVERA, G.; HAGNAUER, W. Modification of vegetative phenology in a tropical semi-deciduous forest by abnormal drought and rain. Biotropica, Washington, v. 34, p. 27-39, 2002.

BRIENEN, R. J. W. Tree rings in the tropics; a study on growth and ages of Bolivian rain forest trees. 2005. I44 p. Thesis (Ph.D. in Forest Management) - Utrecht University, Utrecht, 2005.

BRIENEN, R. J. W.; LEBRIJA-TREJOS, E.; ZUIDEMA, P. A.; MARTÍNEZ-RAMOS, M. Climate-growth analysis for a Mexican dry forest tree shows strong impact of sea surface temperatures and predicts future growth declines. Global Change Biology, Oxford, v. I6, p. 200I-20I2, 2010.

BRIENEN, R. J. W.; WANEK, W.; HIETZ, P. Stable carbon isotopes in tree rings indicate improved water use efficiency and drought responses of a tropical dry forest tree species. Trees: Structure and Function, Berlin, v. 25, p. 103-I I3, 2011 .

BRIENEN, R. J. W.; ZUIDEMA, P. A. The use of tree rings in tropical forest management: projecting timber yields of four Bolivian tree species. Forest Ecology and Management, Amsterdam, v. 226, p. 256-267, 2006.

CALIXTO JÚNIOR, J. T.; DRUMOND, M. A.; ALVES JÚNIOR, F. T. Estrutura e distribuição espacial de Mimosa tenuiflora (Willd.) Poir. em dois fragmentos de Caatinga em Pernambuco. Caatinga, Mossoró, v. 24, n. 2, p. 95-100, 2011 .

CAMPOS, C. H. O.; GRAÇA, L. R.; RIBAS, L. C. A produtividade do bracatingal tradicional através do tempo (Yield of traditionally managed bracatinga (Mimosa scabrella, Benth) through time). Boletim de Pesquisa Florestal, Colombo, n. 12, p. 35-46, 1986.

CHOWDHURY, M. Q.; SCHMITZ, N.; VERHEYDEN, A.; SASS-KLAASSEN, U.; KOEDAM, N.; BEECKMAN, $H$. Nature and periodicity of growth rings in two Bangladeshi mangrove species. IAWA Journal, Utrecht, v. 29, p. 265276, 2008.

COURALET, C.; SASSKLAASSEN, U.; STERCK, F; BEKELE, T.; ZUIDEMA, P. Combining dendrochronology and matrix modeling in demographic studies: an evaluation for in Ethiopia. Forest Ecology and Management, Amsterdam, v. 216, p. 317-330, 2005.

CUVILAS, C. A.; JIRJIS, R.; LUCAS, C. Energy situation in Mozambique: a review. Renewable and Sustainable Energy Reviews, Amsterdam, v. I4, p. 2139-2I46, 2010.

DAVISON, A. C.; HINKLEY, D. V. Bootstrap methods and their application. Cambridge: Cambridge University, 1997. 582 p. (Cambridge Series in Statistical and Probabilistic Mathematics).
ENQUIST, B. J.; LEFFLER, A. J. Long-term tree ring chronologies from sympatric tropical dry-forest trees: individualistic responses to climatic variation. Journal of Tropical Ecology, Cambridge, v. I7, p. 4I-60, 200 I.

FICHTLER, E.; TROUET, V.; BEECKMAN, H.; COPPIN, P.; WORBES, M. Climatic signals in tree rings of Burkea africana and Pterocarpus angolensis from semiarid forests in Namibia. Trees, Trees: Structure and Function, Berlin, v. I8, p. 442-45।, 2004

FIGUEIROA, J.; PAREYN, F.; ARAUJO, E.; SILVA, C.; SANTOS, V.; CUTLER, D.; BARACAT, A.; GASSON, P. Effects of cutting regimes in the dry and wet season on survival and sprouting of woody species from the semi-arid caatinga of northeast Brazil. Forest Ecology and Management, Amsterdam, v. 229, p. 294-303, 2006.

FREITAS, R. A. C.; SIZENANDO FILHO, F. A.; MARACAJÁ, P. B.; DINIZ FILHO, E. T.; LIRA, J. F. B. Estudo florístico e fitosociológico do extrato arbustivo-arboreo de dois ambientes em Messias Targino divisa RN/PB. Revista Verde, Mossoró, v. 2, p. I35-147, 2007.

GEBREKIRSTOS, A.; MITLÖHNER, R.; TEKETAY, D.; WORBES, M. Climate-growth relationships of the dominant tree species from semi-arid savanna woodland in Ethiopia. Trees: Structure and Function, Berlin, v. 22, p. 63I-64I, 2008.

GIULIETTI, A. M.; HARLEY, R. M.; QUEIROZ, L. P.; BARBOSA, M. R. V.; BOCAGE NETA, A. L.; FIGUEIREDO, M. A. Espécies endêmicas da Caatinga. In: SAMPAIO, E. V. S. B.; GIULIETTI, A. M.; VIRGÍNIO, J.; GAMARRA-ROJAS, C. F. L. (Ed.). Vegetação e flora da Caatinga. Recife: Associação Plantas do Nordeste, 2002. p. I03-I05.

KREPKOWSKI, J.; BRÄUNING, A.; GEBREKIRSTOS, A.; STROBL, S. Cambial growth dynamics and climatic control of different tree life forms in tropical mountain forest in Ethiopia. Trees: Structure and Function, Berlin, v. 25, p. 59-70, 2011 .

KROL, M. S.; BRONSTERT, A. Regional integrated modelling of climate change impacts on natural resources and resource usage in semi-arid Northeast Brazil. Environmental Modelling and Software, Oxford, v. 22, p. 259-268, 2007.

LACERDA, A. V. D.; NORDI, N.; BARBOSA, F. M.; WATANABE, T. Levantamento florístico do componente arbustivoarbóreo da vegetação ciliar na bacia do rio Taperoá, PB, Brasil. Acta Botanica Brasilica, Porto Alegre, v. 19, p. 647-656, 2005.

LIMA, A. L. A.; RODAL, M. J. N. Phenology and wood density of plants growing in the semi-arid region of northeastern Brazil. Journal of Arid Environment, London, v. 74, p. |363-1373, 2010. 
LOPEZ, B. C.; RODRIGUEZ, R.; GRACIA, C. A.; SABATE, S. Climatic signals in growth and its relation to ENSO events of two Prosopis species following a latitudinal gradient in South America. Global Change Biology, Oxford, v. I2, p. 897-906, 2006.

LOPEZ, L.; VILLALBA, R. Climate Influences on the Radial Growth of Centrolobium microchaete, a Valuable Timber Species from the Tropical Dry Forests in Bolivia. Biotropica, Washington, v. 43, p. 4I-49, 201 I.

MACHADO, S. A.; FIGURA, M. A.; SILVA, L. C. R.; TÉO, S. J.; STOLLE, L.; URBANO, E. Modelagem volumétrica para bracatinga (Mimosa scabrella) em povoamentos da Região Metropolitana de Curitiba. Pesquisa Florestal Brasileira, Colombo, n. 56, p. 17-29, 2008.

MARKESTEIJN, L.; IRAIPI, J.; BONGERS, F; POORTER, L. Seasonal variation in soil and plant water potentials in a Bolivian tropical moist and dry forest. Journal of Tropical Ecology, Cambridge, v. 26, p. 497-508, 2010.

MATTOS, P. P.; SALIS, S. M.; BRAZ, E. M.; CRISPIM, S. M. A. Sustainable management of natural forests in Pantanal Region, Brazil. Ciência Florestal, Santa Maria, v. 20, p. $321-333,2010$.

MATTOS, P. P.; SEITZ, R. A. Growth dynamics of Anadenanthera colubrina var. cebil and Tabebuia impetiginosa from Pantanal Mato-grossense, Brazil. Ciência Florestal, Santa Maria, v. 18, p. 427-434, 2008.

MIAH, M.; ALRASHID, H.; SHIN, M. Wood fuel use in the traditional cooking stoves in the rural floodplain areas of Bangladesh: a socio-environmental perspective. Biomass and Bioenergy, Oxford, v. 33, p. 70-78, 2009.

MOSTACEDO, B.; PUTZ, F. E.; FREDERICKSEN, T. S.; VILLCA, A.; PALACIOS, T. Contributions of root and stump sprouts to natural regeneration of a logged tropical dry forest in Bolivia. Forest Ecology and Management, Amsterdam, v. 258 , p. 978-985, 2009.

NICOLINI, G.; TARCHIANI, V.; SAURER, W.; CHERUBINI, P. Wood-growth zones in Acacia seyal Delile in the Keita Valley, Niger: is there any climatic signal? Journal of Arid Environment, London, v. 74, p. 355-359, 2010.

PRIOR, L. D.; BROOK, B. W.; WILLIAMS, R. J.; WERNER, P. A.; BRADSHAW, C. J. A.; BOWMAN, D. M. J. S. Environmental and allometric drivers of tree growth rates in a north Australian savanna. Forest Ecology and Management, Amsterdam, v. 234, p. 164-180, 2006.

RIEGELHAUPT, E. M.; PAREYN, F. G. C. A questão energética e o manejo florestal da Caatinga. In: GARIGLIO, M. A.; SAMPAIO, E. V. S. B.; CESTARO, L. A.; KAGEYAMA, P. Y. (Ed.). Uso e conservação dos recursos florestais da Caatinga. Brasília: SFB, 2010. p. 65-75.
RODRIGUEZ, R.; MABRES, A.; LUCKMAN, B.; EVANS, M.; MASIOKAS, M.; EKTVEDT, T. M. El Niño events recorded in dry-forest species of the lowlands of northwest Peru. Dendrochronologia, Jena, v. 22, p. |81-186, 2005.

SAMPAIO, E.; GASSON, P.; BARACAT, A.; CUTLER, D.; PAREYN, F; LIMA, K. C. Tree biomass estimation in regenerating areas of tropical dry vegetation in northeast Brazil. Forest Ecology and Management, Amsterdam, v. 259, p. I|35-||40, 2010.

SCHONGART, J. Growth-Oriented Logging (GOL): a new concept towards sustainable forest management in Central Amazonian varzea floodplains. Forest Ecology and Management, Amsterdam, v. 256, p. 46-58, 2008.

SCHONGART, J.; ORTHMANN, B.; HENNENBERG, K. J.; POREMBSKI, S.; WORBES, M. Climate-growth relationships of tropical tree species in West Africa and their potential for climate reconstruction. Global Change Biology, Oxford, v. I2, p. II39-I I50, 2006.

SILVA, I. M. M. S. da; MARANGON, L. C.; HANAZAKI, N.; ALBUQUERQUE, U. P. Use and knowledge of fuelwood in three rural caatinga (dryland) communities in NE Brazil. Environment, Development and Sustainability, Dordrecht, v. II, p. 833-85 I, 2009.

SILVA, L. B.; SANTOS, F. A. R.; GASSON, P.; CUTLER, D. Estudo comparativo da madeira de Mimosa ophthalmocentra Mart. ex Benth e Mimosa tenuiflora (Willd.) Poir. (Fabaceae-Mimosoideae) na caatinga nordestina. Acta Botanica Brasilica, Porto Alegre, v. 25, n. 2, p. 30I-3I4, $201 \mathrm{I}$.

SILVA, V. P. R. On climate variability in Northeast of Brazil. Journal of Arid Environment, London, v. 58, p. 575-596, 2004.

STURION, J. A.; PEREIRA, J. C. D.; CHEMIN, M. S. Qualidade da madeira de Eucalyptus vimanalis para fins energéticos em função do espaçamento e idade de corte. Boletim de Pesquisa Florestal, Colombo, n. 16, p. 55-59, 1988.

STURION, J. A.; TOMASELLI, I. Influência do tempo de estocagem de lenha de bracatinga na produção de energia. Boletim de Pesquisa Florestal, Colombo, n. 21 , p. 3747, 1990.

TOLEDO, M.; POORTER, L.; PEÑA-CLAROS, M.; ALARCÓN, A.; BALCÁZAR, J.; LEAÑO, C.; LICONA, J. C.; LLANQUE, O.; VROOMANS, V.; ZUIDEMA, P.; BONGERS, F. Climate is a stronger driver of tree and forest growth rates than soil and disturbance. Journal of Ecology, Durham, v. 99, p. 254-264, 2011.

VELLOSO, A. L.; SAMPAIO, E. V. S. B.; PAREYN, F. G. C. (Ed.). Ecorregióes: propostas para o bioma caatinga. Aldeia: APNE, 2002. $81 \mathrm{p}$. 
VILLEGAS, Z.; PEÑA-CLAROS, M.; MOSTACEDO, B.; ALARCÓN, A.; LEAÑO, C.; PARIONA, W.; CHOQUE, $U$. Silvicultural treatments enhance growth rates of future crop trees in a tropical dry forest. Forest Ecology and Management, Amsterdam, v. 258, p. 97I-977, 2009.

VOLLAND-VOIGT, F.; BRÄUNING, A.; GANZHI, O.; PETERS, T.; MAZA, H. Radial stem variations of Tabebuia chrysantha (Bignoniaceae) in different tropical forest ecosystems of southern Ecuador. Trees, Berlin, v. 25, p. $39-48,2011$.
WILS, T. H. G.; SASS-KLAASSEN, U. G. W.; ESHETU, Z.; BRÄUNING, A.; GEBREKIRSTOS, A.; COURALET, C.; ROBERTSON, I.; TOUCHAN, R.; KOPROWSKI, M.; CONWAY, D.; BRIFFA, K. R.; BEECKMAN, $H$. Dendrochronology in the dry tropics: the Ethiopian case. Trees, Berlin, v. 25, p. 345-354, 201 I.

WORBES, M.; STACHEL, R.; ROLOFF, A.; JUNK, W. J. Tree ring analysis reveals age structure, dynamics and wood production of a natural forest stand in Cameroon. Forest Ecology and Management, Amsterdam, v. I73, p. 105-123, 2003. 